\title{
Early-career psychiatrists studying psychopharmacology in Oxford - a report from the ECNP School of Neuropsychopharmacology, 30 June-5 July 2019, Oxford, United Kingdom
}

\author{
Młodzi psychiatrzy uczą się psychofarmakologii w Oksfordzie. Sprawozdanie \\ z ECNP School of Neuropsychopharmacology, 30 czerwca-5 lipca 2019 r., \\ Oksford, Wielka Brytania
}

Tomasz M. Gondek ${ }^{1}$ Magdalena Więdłocha², Dominik Wincewicz ${ }^{3}$

\section{Introduction}

The European College of Neuropsychopharmacology (ECNP) is a pan-European, international organisation which aims to foster the knowledge about functioning of the human brain and neuropharmacological treatments, as well as to promote pre-clinical and clinical research in this area and to support the development of early career researchers in order to work towards identifying better interventions to prevent and treat mental and neurological disorders.

ECNP was established in 1985 and in 1987 held its first scientific congress in Brussels. Since then, scientific congresses have been organised annually and new educational initiatives, dedicated mainly to early career researchers, psychiatrists and neuroscientists, have been developed. Currently, apart from the congresses, the organisation offers the possibility to participate in (1) workshops for young scientists and trainees, such as the ECNP Workshop for Early Career Scientists in Europe or the ECNP Workshop on Clinical Research Methods; (2) schools for early career scientists, e.g. the ECNP School of Neuropsychopharmacology and the ECNP School of Child and Adolescent Neuropsychopharmacology; and (3) ECNP Seminars and Research Internships in various countries across the world. Meetings and courses prepared by the ECNP have always been well-regarded by the participants and offered very high professional level. They also create the possibility to build a network of contacts between young researchers, which often can turn into a long-term scientific collaboration.

Here, we present a report from the 2019 ECNP School of Neuropsychopharmacology that took place between 30 June and 5 July 2019 in Oxford, United Kingdom. 


\section{Sunday, 30 June 2019 (Day 1)}

The first day of the ECNP School of Neuropsychopharmacology began with registration of the participants. The opening of the learning programme was scheduled for the afternoon; therefore, some of us who arrived early decided to take a walk around Oxford and admire the sight of the historic buildings of the university colleges and the richness of shades of green fields adjacent to the city.

At the beginning, each of us introduced ourselves to the whole group of participants and presented their professional and scientific interests. Professor Guy Goodwin gave an inaugural speech, presenting the directions of the current ECNP activities and discussing the entire training programme of this year's ECNP School of Neuropsychopharmacology. In addition to the lectures and seminars planned for every day of the meeting, its axis was to work in groups through the whole school on the preparation of our own research projects in the area of treatment of mental disorders. Professor Goodwin declared that interesting projects proposed by the participants might be picked up by the faculty and carried on further with the support of the ECNP.

The ECNP for years now have promoted a new way of classifying psychopharmacological agents, known as the neuroscience-based nomenclature. Professor Joseph Zohar from Israel gave a lecture entitled, "Why should I use the new Neuroscience Based Nomenclature of psychotropics?" He presented the rationale behind the change of the psychotropic drugs classifications commonly used so far, considering that many drugs are now being used in not just one but in various diagnoses or symptoms, which are not necessarily linked with the name of the group the drug was previously placed in. For example, quetiapine, classified so far as an antipsychotic, apart from the treatment of psychoses, can very well be used in the treatment of unipolar depression, bipolar disorder or even insomnia, which may be confusing, particularly for the patients, why they are prescribed an antipsychotic drug for depression. It is therefore not useful anymore to continue with such a classification and shifting the focus on the mechanism of action of drugs is proposed in this approach instead.

At the end of the day, we were served welcome dinner in the dining room of St. Catherine's College during which we had the opportunity to get to know other participants better.

\section{Monday, 1 July 2019 (Day 2)}

The main teaching programme started on Monday. Straight away we were asked to form the groups and discuss "what the big treatment questions for anxiety disorders, schizophrenia, mood disorder are?" Each group had then to decide on the most important question in their opinion and prepare a design of a study to find the answer.

The lectures on that day focused on the field of anxiety disorders. We listened to the lecture by Dr. Christer Allgulander from Sweden on the "Treatment of anxiety disorders: where is the room for improvement?" Dr. Allgulander presented various aspects of diagnosing and managing generalised anxiety disorder, social anxiety disorder, panic disorder, as well as their medical and socioeconomic consequences. Then Prof. Zohar continued the topic and presented his views in the lecture entitled, "DSM 5: new perspective on 'anxiety disorders' - treatment implications," which then sparked an interesting discussion on treatment modalities between the faculty and the participants.

After the lunch break, we were randomly divided into smaller groups for two clinical case sessions chaired by Dr. Allgulander and Prof. Zohar. Prior to the School, we were asked to prepare presentations on interesting or controversial case reports. Prof. Goodwin himself selected the most interesting cases and included their presentations by the participants in the programme. The session were very interactive, each presentation was followed by long discussion moderated by one of the chairs.

Later, all the participants reunited in the main hall of the School for the workshop on "How to organise a meeting". Prof. Goodwin and Audrey Dufour from the Lundbeck Institute in Denmark presented the joint initiatives fostered by the two organisations. Audrey Dufour described how the Lundbeck Institute seminars (covering the topics of mood disorders, schizophrenia, dementia or Parkinson's disease) are organised, invited us to take part also in these meetings and presented valuable learning resources provided by the Lunbeck Institute and available at the https://institute.progress.im website.

The poster session concluded the learning activities of the day. Each participant was asked before the School to bring to Oxford a poster presenting their own research. Similarly to the poster sessions at the ECNP Congresses, authors of posters with odd numbers presented their work during the first half of the session and had the chance to join the poster walk in the second half, during which the authors of posters with even numbers presented theirs. It allowed us to understand one another's research background and discuss a variety of topics we have worked on.

\section{Tuesday, 2 July 2019 (Day 3)}

The first part of the seminar on the second day was dedicated to the topic of psychotic disorders. At the beginning, Kate Saunders (UK) explained a new approach to the diagnostics of psychosis. It includes staging models 
of symptoms, both clinical and subclinical, as well as dimensions that are not taken into account in a traditional classification. The researcher talked through the therapeutic implications of understanding psychosis as a continuum, starting with the increased risk of psychosis at stage 0 , through mild or not specific symptoms and functional changes (stage 1a), ultra-high risk state (stage $1 b)$, full threshold disorder with moderate-severe symptoms (stage 2), incomplete remission or recurrence (stage 3 ) and severe, persistent symptoms and disability (stage 4). Differentiating sub-syndromal from clear disorder enables the clinician to select treatments relevant to earlier stages of an illness and assumes that such interventions will be both more effective and less harmful than treatments delivered later in the course of the illness. Kate Saunders emphasised that progression is not inevitable. In the subsequent seminar, Bill Deakin (UK) presented the current state of knowledge on biomarkers in psychosis that can potentially be useful in schizophrenia diagnostics and treatment.

During casuistic workshops various therapeutic difficulties concerning schizophrenia treatment were presented. Experts and participants discussed negative symptomatology, a poor response to treatment in a patient with the first episode of schizophrenia, as well as using clozapine as a first-line therapy. Moreover, we talked through the case of a patient who, probably due to polypharmacotherapy, developed a life-threatening condition, i.e. neuroleptic malignant syndrome. Experts emphasised how important it is to follow the therapeutic guidelines and avoid combining antipsychotics unless there are specific indications. Such an indication was presented in another clinical case, when adjunctive treatment with aripiprazole was used to resolve risperidone induced hyperprolactinemia.

The second part of the seminar was dedicated to the use of deep brain stimulation (DBS) in various mental disorders. Damiaan Denys (The Netherlands) talked about his numerous experiences in DBS application to patients suffering from obsessive-compulsive disorder, major depressive disorder as well as Tourette syndrome. The researcher explained possible therapeutic benefits and adverse effects of neurostimulation. Also, participants could watch a film presenting changes in a patient's mental state before and after DBS application. Afterwards, the researcher Gerry Dawson (UK), who cooperated with pharmaceutical concerns for many years, presented a process of investigating and introducing new medicines. He explained the construction of clinical trials and discussed why they often seem to be inadequate to the therapeutic reality. Gerry Dawson showed the difficulties that may occur at the interface between science and pharmaceutical business. Also, there was an opportunity to face this complicated and expensive process of developing new drugs while working in several "research groups" equipped with fictitious funds.

\section{Wednesday, 3 July 2019 (Day 4)}

On day 4, we participated in seminars run by Andrea Cipriani - an international expert on meta-analysis in psychiatry. This researcher is the co-author of over a dozen meta-analysis and systematic reviews published in leading medical journals. During the seminars, he showed the basics of creating meta-analyses and network meta-analyses, as well as highlighted serious mistakes that are sometimes made, enabling the interpretation and evaluation of several published meta-analyses results and conclusions. Also, Andrea Cipriani presented how this statistical data can be practically applied in individual patient treatment. The newly acquired skills and information was applied to network meta-analyses during group exercises.

After the seminar series, the programme offered a free afternoon for participants to spend their time together exploring the city, enjoying new acquaintances and discovering Oxford's charm.

\section{Thursday, 4 July 2019 (Day 5)}

The fifth day of the School was mainly focused on pharmacotherapy of depression. This was introduced by Hamish McAllister-Williams, MD, PhD, Professor of Affective Disorders Unit at Newcastle University (UK). His lecture was dedicated to the goals and principals of managing difficult to treat depression (DTD) in contrast to treatment resistant depression (TRD), as well as a clinical and research roadmap for when remission is elusive. It was highlighted that the optimal assessment of DTD is tridimensional, which includes treatment factors (e.g. number of failed treatments; nature of treatments: drugs vs psychotherapy; quality, tolerability and adherence), person factors (e.g. personality, genetics, psychosocial factors), and illness factors (e.g. diagnosis: MDD vs BP, course of the disease: chronic vs recurrent, comorbidities, age of onset). This was followed by a comparison of standard treatment, based on clinicians' choice decisions, to measurement-based care applying guideline- and rating scale-based decisions in major depression. Predominant feasibility and effectiveness of the measurement-based care was a clear outcome. Finally, augmentation options in depression treatment, using pharmacological and non-pharmacological strategies as well as novel promising treatment options (esketamine, psilocybin), were discussed.

Afterwards, Eric Ruhe, $\mathrm{PhD}$ a researcher from the Donders Institute for Brain, Cognition and Behaviour (NL), reviewed the receptor and molecular modes of action, as well as clinical relevance of mechanisms of actions of the drugs with mood regulating capacity. This presentation included a brief evaluation of cognitive neuropsychological models, based on change in emotional bias, for early 
prediction of pharmacological treatment outcome. Moreover, the hypothesis of chemical imbalance, as a primary cause of mood disorders, was challenged. This included discussion on plastic changes in neuronal connectivity as a result of depression and anti-depressive treatment, which along with neuroimaging data lead to new insight into neuroscience of mood disorders, based on wholebrain computational modelling.

This was followed by a clinical case session devoted to differential diagnosis of depression and bipolar disorder. First, a case of a patient initially diagnosed with depression with mixed features, was presented. The diagnosis was followed by 4 years of insufficient treatment with paroxetine and venlafaxine, which lead to rapid cycling depression with serious suicidal attempts. This mixed state induced by SSRI/SNRI was treated with electroconvulsive therapy and lithium, which resulted in long term remission. Second clinical case, regarding postpartum depression syndrome, was dominated by the excitement associated with brexanolone treatment.

The afternoon lecture that day was given by Filip Nuss, MD, PhD, Psychiatric and Medical Psychology Department, Saint-Antoine Sorbonne University, Paris (FR). The boundaries of bipolar disorder were discussed with regard to creativity as its 'successful' outcome. The challenging complicity of clinical situations with bipolar features was explored along with the issue of comorbidity. It was highlighted that in complex clinical situations context-based attitude and holistic approach is necessary to implement the optimal treatment. The lecturer led us step by step to an inspiring conclusion, that artistic creation, clinical practice, and research share common determinants, whereas nourishing clinicians shall read the symptoms to develop an integrative understanding of the wealth of the multi semantic value of signs.

The final talk that day was given by the host of the School, Guy Goodwin, MD, DPhil, Professor of Psychiatry at the University of Oxford (UK). He addressed the issue of 'fake news' and misinformation regarding psychopharmacology in mass media. He also suggested that those should be addressed with quality clinical research with well-designed randomised clinical trials along with practicing evidence-based medicine. The key components of successful clinical trials as well data interpretation issues were discussed.

\section{Wprowadzenie}

European College of Neuropsychopharmacology (ECNP) jest międzynarodową organizacją, której celem jest jest pogłębianie wiedzy na temat funkcjonowania ludzkiego

\section{Friday, 5 July 2019 (Day 6)}

On the last of the School, we summarised the newly introduced group exercise and attempted to address the „big treatment questions.” Each group selected a speaker who presented the effects of the group's weekly work on one of the topics listed below:

Should we use DA-5HT antagonists for indications not supported by the randomised clinical trials?

Should we use clozapine as the first line treatment in the first episode of SCZ: the cost/benefit risk?

Should we treat depressive symptoms in patients with personal disorders following guidelines for MD or BP?

What treatments are effective for impulsivity?

The final lecture of the meeting was given by Guy Goodwin, who shared several details of the field of his expertise in bipolar disorder. This included insight into accurate diagnoses of sub-groups of bipolar disorders according to DSM-5, but also into bipolar phenotype including the spectrum of the disease. A valuable remark has been made on the diagnosis of temper dysregulation disorder with dysphoria, which narrows misleading diagnosis of bipolar in young age. Evidence-based guidelines for treating bipolar disorder were revisited. This included revision of the categories of evidence as well as the grade of recommendations. This was followed by the summary and official closing of the School.

\section{Conclusions}

In summary, the ECNP School of Neuropsychopharmacology is a week-long course that not only covers the fundamentals of neuropsychopharmacology, but most importantly changes the perception of treatment of brain disorders. This is an initiative that truly applies the achievements of clinical neuroscience through the use of medications in individual indications, good clinical practice and optimal treatment and algorithms. The details of the School as well as other initiatives, such as congresses, training, seminars and workshops organised by the European College of Neuropsychopharmacology can be found at: https://www.ecnp.eu/, in the "early career" section.

The authors wish to take this opportunity to thank all those who made their participation in the $11^{\text {th }}$ School of Neuropsychopharmacology possible.

mózgu i neuropsychofarmakologii, promowanie badań przedklinicznych i klinicznych $w$ tej dziedzinie oraz wspieranie rozwoju badaczy u progu swych karier, aby poszukiwać interwencji skuteczniejszych w zapobieganiu zaburzeniom psychicznym i neurologicznym i w ich leczeniu. 
ECNP powstało w 1985 roku, zaś w 1987 roku w Brukseli odbył się pierwszy kongres naukowy stowarzyszenia. Od tego czasu co roku organizowane są kongresy naukowe ECNP Congress, ponadto stale rozwijane są także nowe inicjatywy edukacyjne, skierowane głównie do młodych badaczy w obszarze neuronauki oraz do młodych psychiatrów. Obecnie, poza kongresami, organizacja oferuje możliwość uczestnictwa: $\mathrm{w}$ warsztatach dla młodych naukowców i rezydentów, takich jak ECNP Workshop for Early Career Scientists in Europe lub ECNP Workshop on Clinical Research Methods, szkołach letnich: ECNP School of Neuropsychopharmacology i ECNP School of Child and Adolescent Neuropsychopharmacology; a także seminariach i stażach naukowych w różnych krajach na całym świecie. Szkolenia i kursy przygotowane przez ECNP od lat były wysoko oceniane przez ich uczestników i stały na bardzo wysokim poziomie merytorycznym. Stwarzają one jednocześnie możliwość budowania sieci kontaktów między młodymi naukowcami, co często może przerodzić się później w długotrwałą współpracę naukową.

Niniejszym prezentowane jest sprawozdanie ze szkoły ECNP School of Neuropsychopharmacology, która odbyła się w dniach od 30 czerwca do 5 lipca 2019 roku w Oksfordzie w Wielkiej Brytanii.

\section{Niedziela, 30 czerwca 2019 (dzień pierwszy)}

Pierwszy dzień Szkoły Neuropsychofarmakologii rozpoczął się od rejestracji uczestników. Początek programu edukacyjnego zaplanowano na popołudnie, dlatego niektórzy z nas, przybywszy wcześniej, postanowili wybrać się na spacer po Oksfordzie, by móc podziwiać widoki historycznych budynków uniwersyteckich college'ów, a także bogactwo odcieni zielonych pól przylegających do miasta.

Na początku każdy z nas przedstawił się całej grupie uczestników i zaprezentował swoje zainteresowania zawodowe i naukowe. Prof. Guy Goodwin wygłosił przemówienie inauguracyjne, prezentując kierunki bieżących działań ECNP i omawiając cały program szkoleniowy tegorocznej Szkoły Neuropsychofarmakologii. Oprócz wykładów i seminariów zaplanowanych każdego dnia tego wydarzenia, jego główną osią, od początku do końca spotkania, miała być praca w grupach nad przygotowaniem naszych projektów badawczych w dziedzinie leczenia zaburzeń psychicznych. Prof. Goodwin oświadczył, że ciekawe projekty zaproponowane przez uczestników mogą zostać zauważone przez prowadzących i w późniejszym czasie kontynuowane przy wsparciu udzielonym przez ECNP.

ECNP od lat promuje nowy sposób klasyfikowania leków psychotropowych, znany jako neuroscience-based nomenclature. Prof. Joseph Zohar z Izraela wygłosił wykład zatytułowany: „Dlaczego powinienem korzystać z nowej nomenklatury leków psychotropowych opartej na neuronauce?". Przedstawił uzasadnienie zmiany powszechnie stosowanych dotychczas klasyfikacji leków psychotropowych, zwracając uwagę, że wiele z nich jest obecnie stosowanych nie w jednej, ale w różnych diagnozach lub przy różnych objawach, które niekoniecznie mają związek z nazwą grupy, w której umieszczano dotychczas dany lek. Na przykład kwetiapina, sklasyfikowana do tej pory jako środek przeciwpsychotyczny, oprócz leczenia psychoz może z powodzeniem być stosowana w leczeniu depresji jednobiegunowej, choroby afektywnej dwubiegunowej, a nawet bezsenności - i może być to niejasne, zwłaszcza dla pacjentów, dlaczego przepisywane są im leki przeciwpsychotyczne, gdy chorują przecież na depresję. $Z$ tego względu kontynuowanie dotychczasowej klasyfikacji wydaje się już nie szczególnie przydatne, a zamiast tego proponuje się oparcie klasyfikacji na mechanizmach działania poszczególnych leków.

Pod koniec dnia mieliśmy okazję uczestniczyć w powitalnej kolacji w jadalni St. Catherine's College, podczas której mogliśmy lepiej poznać innych uczestników.

\section{Poniedziałek, 1 lipca 2019 (dzień drugi)}

Właściwy program edukacyjny rozpoczął się w poniedziałek. Od początku poproszono nas o podzielenie się na grupy i dyskusję o tym, jakie są obecnie w dyskursie naukowym znaczące pytania dotyczące leczenia zaburzeń lękowych, schizofrenii, zaburzeń nastroju. Każda grupa musiała następnie zdecydować o najważniejszym w swojej opinii pytaniu i przygotować projekt badania, aby móc znaleźć na nie odpowiedź.

Wykłady tego dnia koncentrowały się na obszarze zaburzeń lękowych. Wysłuchaliśmy wykładu dr. Christera Allgulandera ze Szwecji pod tytułem: „Leczenie zaburzeń lękowych: gdzie można je poprawić?”. Dr Allgulander przedstawił różne aspekty diagnozowania i leczenia zaburzenia lękowego uogólnionego, lęku społecznego, zespołu lęku napadowego, a także ich konsekwencje medyczne i społeczno-ekonomiczne. Następnie prof. Zohar kontynuował ten temat i przedstawił własne spojrzenie w wykładzie zatytułowanym: „DSM 5: nowa perspektywa zaburzeń lękowych - implikacje lecznicze", który podsumowany został interesującą dyskusją na temat sposobów leczenia tych zaburzeń między prowadzącymi a uczestnikami Szkoły.

Po przerwie na lunch zostaliśmy losowo podzieleni na mniejsze grupy, by wziąć udział w dwóch sesjach, pod przewodnictwem dr. Allgulandera i prof. Zohara, poświęconych prezentacji istotnych przypadków klinicznych. Przed rozpoczęciem Szkoły w Oksfordzie poproszono nas o przygotowanie prezentacji na temat interesujących lub kontrowersyjnych przypadków z naszej praktyki. Prof. Goodwin osobiście wybrał najciekawsze przypadki i umieścił w programie prezentacje ich autorów. Sesje te były niezwykle interaktywne, po każdej prezentacji 
rozwijała się długa dyskusja, moderowana przez jednego z prowadzących.

Następnie wszyscy uczestnicy zebrali się ponownie w głównej sali wykładowej, by wziąć udział w warsztatach pod tytułem: „Jak zorganizować spotkanie naukowe”. Prof. Goodwin i Audrey Dufour z duńskiego Lundbeck Institute przedstawili wspólne inicjatywy rozwijane przez obie organizacje. Audrey Dufour zaprezentowała, w jaki sposób organizowane są seminaria Lundbeck Institute (obejmujące tematy związane z zaburzeniami nastroju, schizofrenią, demencją lub chorobą Parkinsona), zaprosiła nas do wzięcia udziału również w tych spotkaniach oraz przedstawiła cenne zasoby edukacyjne przygotowane przez Lundbeck Institute i dostępne na stronie https:// institute.progress.im.

Zajęcia edukacyjne tego dnia zostały podsumowane sesją plakatową. Każdy z uczestników został poproszony przed przyjazdem o przygotowanie i przywiezienie do Oksfordu plakatu przedstawiającego prowadzone przez siebie badania. Podobnie jak w przypadku sesji plakatowych odbywających się podczas kongresów ECNP, autorzy plakatów ponumerowanych nieparzystymi liczbami prezentowali swoje prace w pierwszej połowie sesji, po czym mieli okazję w drugiej jej połowie przejść wzdłuż stanowisk, gdy autorzy plakatów ponumerowanych liczbami parzystymi stali się tym razem osobami prezentującymi. Umożliwiło nam to poznanie naszych wzajemnych doświadczeń na polu badawczym i omówienie podobnych zagadnień, nad którymi pracowaliśmy w swoich ośrodkach.

\section{Wtorek, 2 lipca 2019 (dzień trzeci)}

Pierwsza część zajęć w tym dniu była poświęcona zaburzeniom psychotycznym. Wykład Kate Saunders (Wielka Brytania) dotyczył podejścia diagnostycznego do psychozy ,uwzględniającego stopień zaawansowania objawów, w tym stadia subkliniczne oraz wymiary niebrane pod uwagę w tradycyjnej klasyfikacji. Badaczka przedstawiła również implikacje terapeutyczne rozumienia psychozy jako kontinuum, począwszy od podwyższonego ryzyka psychozy (stopień 0), przez łagodne lub niespecyficzne objawy i zmiany funkcjonowania (stopień 1a), stan ultrawysokiego ryzyka psychozy (stopień $1 \mathrm{~b}$ ), pełnoobjawową psychozę o umiarkowanym lub ciężkim nasileniu (stopień 2), niepełną remisję lub nawrót (stopień 3) i ciężkie, przetrwałe objawy powodujące niepełnosprawność (stopień 4). Różnicowanie objawów subklinicznych od tych towarzyszących postępowi i przewlekłości choroby umożliwia interwencję wczesną i ukierunkowaną, a dzięki temu skuteczniejszą. Kate Saunders podkreślała, że progresja choroby nie jest nieunikniona. Kolejne seminarium poprowadził Bill Deakin, zaprezentował on obecny stan wiedzy na temat biologicznych markerów potencjalnie mogących odgrywać znaczącą rolę w diagnostyce i leczeniu schizofrenii.
Sesja przypadków klinicznych również dotyczyła pacjentów chorujących na schizofrenię, u których pojawiły się różne trudności terapeutyczne. Uczestnicy dyskutowali o problemie nasilonych objawów negatywnych, o niezadowalającej odpowiedzi na leczenie w pierwszym epizodzie schizofrenii, a także o możliwości włączania klozapiny jako leczenia pierwszego rzutu. Ponadto przedstawiony został przypadek pacjenta, u którego prawdopodobnie w wyniku polifarmakoterapii wystąpił złośliwy zespół neuroleptyczny. Prowadzący warsztaty eksperci podkreślali, jak ważne dla bezpieczeństwa pacjenta jest stosowanie się do zaleceń dotyczących leczenia schizofrenii i unikanie łączenia leków przeciwpsychotycznych, o ile nie ma do tego konkretnych wskazań. Jedno z nich zostało również przedstawione - dołączanie arypiprazolu do risperidonu w przypadku wystąpienia hiperprolaktynemii.

W dalszej części dnia Damiaan Denys (Holandia) poprowadził seminarium dotyczące zastosowania głębokiej stymulacji mózgu (deep brain stimulation, DBS) w zaburzeniach psychicznych. Badacz opowiedział o swoich licznych doświadczeniach zastosowania DBS w praktyce, m.in. w leczeniu zaburzeń obsesyjno-kompulsywnych, depresyjnych, zespołu Tourette'a. Przedstawił możliwe korzyści terapeutyczne i działania niepożądane, a także film pokazujący zmiany stanu psychicznego u pacjentki $\mathrm{w}$ wyniku stosowania neurostymulacji.

Następnie Gerry Dawson, badacz, który przez wiele lat współpracował z koncernami farmaceutycznymi, przedstawił proces projektowania i wprowadzania ma rynek nowych leków. Tłumaczył sposób konstruowania badań klinicznych oraz pokazywał, dlaczego nie zawsze są one adekwatne do rzeczywistości terapeutycznej. Gerry Dawson przedstawił trudności, jakie mogą pojawić się w sytuacji, w której stykają się dwa światy: nauki i biznesu farmaceutycznego. Badacz zaproponował też uczestnikom osobiste zmierzenie się z procesem projektowania i wprowadzania leku na rynek. W kilku „zespołach badawczych" mieli oni za zadanie wykorzystać przyznane fikcyjne fundusze, by przeprowadzić ten skomplikowany i kosztowny proces.

\section{Środa, 3 lipca 2019 (dzień czwarty)}

W czwartym dniu seminaria prowadzone były przez światowego eksperta zajmującego się metaanalizami w psychiatrii - Andreę Ciprianiego. Badacz jest współautorem kilkunastu metaanaliz i przeglądów systematycznych publikowanych w czołowych czasopismach medycznych. W trakcie zajęć omówił on podstawy tworzenia metaanaliz oraz metaanaliz sieciowych, a także popełniane przy nich poważne błędy. Umożliwiło to interpretację i ocenę pod kątem merytorycznym wyników i wniosków z kilku opublikowanych metaanaliz. Andrea Cipriani zaprezentował też, jak w praktyce wykorzystywać dane 
statystyczne w leczeniu konkretnego pacjenta. Uczestnicy mieli również możliwość zastosowania zdobytych wiadomości w praktyce podczas pracy w grupach nad metaanalizami sieciowymi.

Popołudnie tego dnia było wolne, mogliśmy więc oddać się zwiedzaniu, poznawaniu się i wspólnemu odkrywaniu uroków Oksfordu.

\section{Czwartek, 4 lipca 2019 (dzień piąty)}

Piąty dzień szkoły poświęcony był farmakoterapii depresji. Wykład wprowadzający wygłosił prof. Hamish McAllister-Williams, kierujący Oddziałem Leczenia Chorób Afektywnych Uniwersytetu w Newcastle (Wielka Brytania). Jego prelekcja poświęcona była zdefiniowaniu celów i zasad terapii depresji trudnej w leczeniu (difficult to treat depression, DTD), które kontrastują z terapią depresji lekoopornej (treatment resistant depression, TRD), z uwzględnieniem innych klinicznych oraz badawczych stanów chorobowych, w których uzyskanie remisji pozostaje nieuchwytne. Podkreślona została specyfika optymalnej oceny DTD, która jest trójwymiarowa i obejmuje czynniki związane z leczeniem (np. liczbę nieudanych interwencji; charakter leczenia: farmakoterapia vs. psychoterapia; jakość, tolerancję i współpracę podczas terapii), czynniki związane z pacjentem (np. osobowość, genetyka, czynniki psychospołeczne) i czynniki zależne od choroby (np. diagnoza: MDD vs. BP, przebieg choroby: przewlekły vs. nawracający, choroby współistniejące, wiek manifestacji chorobowej). Następnie porównano efekty leczenia depresji z zastosowaniem standardowego leczenia, opartego na decyzjach lekarzy, z leczeniem bazującym na pomiarach (measurement-based care), uwarunkowanym wytycznymi i skalami oceny. Wnioski jednoznacznie wskazywały na wyższą skuteczność oraz możliwość wdrożenia opieki opartej na pomiarach. Na koniec omówiono terapeutyczne opcje uzupełniające standardowe leczenie depresji, z uwzględnieniem strategii farmakologicznych i niefarmakologicznych, a także nowych obiecujących opcji leczenia (esketamina, psylocybina).

Następnie, dr Eric Ruhe, naukowiec z Donders Institute for Brain, Cognition and Behavior (NL), dokonał przeglądu receptorów oraz efektów molekularnych, a także klinicznego znaczenia mechanizmów działania leków wpływających na regulację nastroju. Prezentacja obejmowała krótką ocenę poznawczych modeli neuropsychologicznych, wykorzystujących złożone procesy przetwarzania doznań emocjonalnych, w celu wczesnego przewidywania możliwych do uzyskania efektów leczenia farmakologicznego. Ponadto zakwestionowano hipotezę zaburzeń neurochemicznych jako głównej przyczyny zaburzeń nastroju. Dyskusja uwzględniała zwięzłe podsumowanie obecnego stanu wiedzy na temat zmian plastyczności neuronalnej powstających zarówno wskutek depresji, jak i leczenia przeciwdepresyjnego, które dzięki zastosowaniu technik funkcjonalnego neuroobrazowania umożliwiły stworzenie modelu obliczeniowego zapewniającego pełniejszy wgląd w neurobiologię zaburzeń nastroju.

Kolejną częścią szkolenia była sesja poświęcona przypadkom klinicznym, o tematyce skupionej na diagnostyce różnicowej depresji i choroby afektywnej dwubiegunowej. Jako pierwszy przedstawiono przypadek pacjenta, u którego początkowo rozpoznano depresję z cechami mieszanymi. Diagnoza skutkowała 4-letnim okresem niesatysfakcjonującego leczenia paroksetyną i wenlafaksyną, manifestacją depresji z szybką zmianą faz oraz poważnymi próbami samobójczymi. W leczeniu stanu mieszanego, wywołanego przez SSRI/SNRI, zastosowano terapię elektrowstrząsową, a następnie lit, uzyskując długoterminową remisję. Omówienie drugiego przypadku klinicznego, dotyczącego zespołu depresji poporodowej, zdominowane było zainteresowaniem nowo wprowadzonym lekiem (z dotychczasową rejestracją jedynie w USA) - brexanolonu.

Wykład popołudniowy tego dnia wygłosił prof. Filip Nuss, kierownik Wydziału Psychiatrii i Psychologii Medycznej Uniwersytetu Saint-Antoine Sorbonne w Paryżu (FR). Stany z pogranicza choroby afektywnej dwubiegunowej zostały omówione w odniesieniu do kreatywności jako „pozytywnego” skutku choroby. Bardzo trudne kliniczne wyzwania diagnostyki stanów z cechami dwubiegunowymi omówiono w kontekście współwystępowania chorobowego. Podkreślono, że w złożonych sytuacjach klinicznych konieczne jest podejście kontekstowe i holistyczne w celu wdrożenia optymalnego leczenia. Wykładowca prowadził nas krok po kroku do inspirującego wniosku, że twórczość artystyczna, praktyka kliniczna oraz badania naukowe mają wspólne determinanty, które wnikliwi klinicyści powinni odkrywać, wypracowując zintegrowane rozumienie bogactwa wielowartościowej symptomatologii.

Ostatni wykład tego dnia wygłosił gospodarz Szkoły, prof. Guy Goodwin, wieloletni kierownik Kliniki Psychiatrii Uniwersytetu w Oksfordzie (Wielka Brytania). Rozpoczął od poruszenia kwestii „fałszywych wiadomości" (fake news) i błędnych informacji dotyczących psychofarmakologii w środkach masowego przekazu. Zasugerował również, że naszą odpowiedzią na takie zakłamania powinno być prowadzenie wysokiej jakości badań klinicznych z dobrze zaprojektowanymi randomizowanymi badaniami klinicznymi oraz praktyka psychiatryczna oparta na dowodach medycznych (evidence based medicine, EBM). Omówiono kluczowe elementy poprawnie przygotowanych i przeprowadzonych badań klinicznych, a także kwestie interpretacji danych.

\section{Piątek, 5 lipca 2019 (dzień szósty)}

Ostatni dzień Szkoły rozpoczęliśmy od podsumowania nowo wprowadzonego ćwiczenia grupowego, próbując 
odpowiedzieć na „istotne pytania dotyczące leczenia”. Każda grupa wybrała mówcę, który przedstawił efekty tygodniowej pracy nad jednym z poniższych problemów:

1. Czy powinniśmy stosować antagonistów DA-5HT poza wskazaniami potwierdzonymi przez randomizowane badania kliniczne?

2. Czy powinniśmy stosować klozapinę jako leczenie pierwszego rzutu w pierwszym epizodzie schizofrenii: ryzyko kosztów/korzyści?

3. Czy powinniśmy leczyć objawy depresyjne u pacjentów z zaburzeniami osobistymi zgodnie z wytycznymi dotyczącymi depresji lub choroby dwubiegunowej?

4. Jakie oddziaływania terapeutyczne są skuteczne w leczeniu impulsywności?

Końcowy wykład zamykający Szkołę wygłosił prof. Guy Goodwin, dzieląc się wybranymi szczegółami z zakresu swojej eksperckiej wiedzy dotyczącej zaburzeń afektywnych dwubiegunowych. Prezentacja obejmowała omówienie diagnostyki podgrup zaburzeń dwubiegunowych zgodnie z DSM-5, z uwzględnieniem fenotypu oraz spektrum dwubiegunowości. Spośród wielu cennych uwag warto wspomnieć tę dotyczącą diagnozy zaburzenia regulacji temperamentu $\mathrm{z}$ dysforią, która zawęża wprowadzające w błąd kryteria diagnostyczne choroby afektywnej dwubiegunowej u dzieci. Końcowa część wykładu była przypomnieniem wytycznych (EMB) dotyczących leczenia choroby afektywnej dwubiegunowej, z uwzględnieniem przeglądu zarówno kategorii dowodów, jak i stopnia zaleceń. Następnie odbyło się podsumowanie i oficjalne zamknięcie Szkoły.

\section{Zakończenie}

Podsumowując, Szkoła Neuropsychofarmakologii ECNP jest tygodniowym kursem, który nie tylko ugruntowuje podstawy neuropsychofarmakologii, ale co najważniejsze, zmienia sposób postrzegania leczenia zaburzeń psychicznych. Jest to inicjatywa, która dokonuje syntezy, wykorzystując osiągnięcia neuronauki klinicznej przez zastosowanie leków w indywidualnych wskazaniach, dobrej praktyki klinicznej oraz optymalnego leczenia i algorytmów. Szczegóły dotyczące szkoły oraz inne inicjatywy, takie jak kongresy, szkolenia, seminaria i warsztaty organizowane przez Europejskie Kolegium Neuropsychofarmakologii można znaleźć na stronie: https://www.ecnp.eu.

Autorzy pragną skorzystać z okazji, aby podziękować wszystkim tym, którzy umożliwili im udział w XXI Szkole Neuropsychofarmakologii w Oksfordzie.
Conflict of interest and financial support was not declared. /

No conflict of interest or funding has been reported.

The work described in this paper has been carried out in accordance with The Code of Ethics of the World Medical Association (Declaration of Helsinki) for experiments involving humans, EU Directive 2010/63/EU for animal experiments and Uniform Requirements for manuscripts submitted to biomedical journals. / Treści przedstawione w artykule są zgodne z zasadami Deklaracji Helsińskiej, dyrektywami EU oraz ujednoliconymi wymaganiami dla czasopism biomedycznych. 